\author{
$110 \mathrm{~kg}$ 대비 $130 \mathrm{~kg}$ 에 도축된 비육돈의 성장효율, \\ 도체 품질 특성 및 수익성 \\ 이철영* · 권오천* · 하덕민* · 신호원* . 이제룡** . 하영주** . 이진희*** · 하승호*** . \\ 김원기*** . 김광위*** . 김두환* \\ 진주산업대학교 동물생명산업 지역협력연구센터*, 경상남도 첨단양돈연구소**, 부경양돈농협***
}

\title{
Growth Efficiency, Carcass Quality Characteristics and Profitability of Finishing Pigs Slaughtered at 130 vs. $110 \mathrm{Kg}$
}

\author{
C. Y. Lee*, O. C. Kwon*, D. M. Ha*, H. W. Shin*, J. R. Lee**, Y. J. Ha**, J. H. Lee***,
} S. H. Ha***, W. K. Kim***, K. W. Kim*** and D. H. Kim*

Regional Animal Industry Research Center, Jinju National University*, Gyeongnam Province Advanced Swine Research Institute**, Pusan and Kyungnam Cooperative Swine Farms Association***

\begin{abstract}
The slaughter weight (wt) is a most important economic factor in swine production. The present study was undertaken to determine if it is feasible to increase the slaughter wt of finishing pigs to $130 \mathrm{~kg}$ without significantly affecting the growth efficiency and carcass quality. One hundred and sixty gilts and 160 barrows born from lean-type Yorkshire $\times$ Landrace $(\mathrm{YL}$ )-dam and Duroc (D)-sire lines, which are most widely used for terminal breeding for pork production in Gyeongsangnam-do, were randomly allocated into 16 pens under a 2 (sex) $\times 2$ (slaughter wt; 110 vs. $130 \mathrm{~kg}$ ) factorial arrangement of treatments. The animals were fed ad libitum a diet containing 3,200 kcal DE/ $/ \mathrm{kg}$ and $15.5 \%$ crude protein. After slaughter at the predetermined wt, yields of trimmed primal cuts and physicochemical characteristics of the longissimus dorsi muscle (LD) were measured or analyzed. Average daily gain was greater $(\mathrm{P}<0.01)$ in barrows than in gilts (0.86 vs. $0.79 \mathrm{~kg})$, but it was not different between the 110 - and $130-\mathrm{kg}$ slaughter wt groups $(\mathrm{P}>0.05)$. Backfat thickness was greater in the 130- vs. $110-\mathrm{kg}$ group in both sexes (gilts: 21.6 vs. $17.6 \mathrm{~mm}$, barrows: 25.1 vs. $20.8 \mathrm{~mm})$. The yield percentage of belly was greater in barrows than in gilts $(21.2$ vs. 20.5\%) and also in the $130-\mathrm{kg}$ vs. $110-\mathrm{kg}$ group (21.4 vs. $20.2 \%$ ). Major physicochemical characteristics of LD including the color, percentage of 48-h drip loss, 24-h pH and percentages of crude protein and fat were not influenced by slaughter wt. Marginal profit of the $130-\mathrm{kg}$ vs. 110-kg market pig was approximately $-20,000$ won/head, which resulted primarily from the heavy carcass weight of the former exceeding the upper limit of the A- or B-grade. However, if it had not been for the carcass weight limit of the current grading system, a 130-kg market pig would have had a potential marginal profit greater than 20,000 won. Results suggest that slaughter wt of lean-line finishing pigs can be increased to $130 \mathrm{~kg}$ without significantly compromising the growth efficiency and carcass quality and accordingly, the upper weight limit of the 'good-grade' carcass needs to be increased or abolished to accommodate the larger market pigs.
\end{abstract}

(Key words : Finishing pig, Growth, Slaughter, Carcass, Primal cut)

Corresponding author : C. Young Lee, Regional Animal Industry Research Center. Jinju National University, Jinju 660-758, Korea

Tel : +82-55-751-3285, FAX : +82-55-753-4422, E-mail : cylee@jinju.ac.kr 


\section{I. 서 론}

양돈업에 있어서 비육돈의 출하체중은 육질 은 물론 수익에도 크게 영향을 미치는 요인이 기 때문에 적정 출하체중 관리는 성공적인 양 돈업의 필수 요건이다(Kim 등, 2005). 생체중이 증가함에 따라 살코기 비율은 낮아지고 지방 비율이 높아지므로 출하돈이 과비육되면 도체 의 지방 함량이 너무 높아 식품으로서의 가치 가 저하될 뿐만 아니라 사료효율 또한 낮아지 기 때문에 비육돈은 자연적으로 일정 체중 이 상 비육할 수 없게 된다.

비육돈의 생체중이 증가하면 등지방두께는 생체중 증가치와 1 차 함수적으로 비례하여 증가 한다(Quijandria와 Robinson, 1971). 최근 Latorre 등(2004)이 보고한 자료에 따르면 비육돈의 생 체중이 매 $10 \mathrm{~kg}$ 증가할 때마다 등지방두께는 측정 부위에 따라 $1.4 \sim 2.4 \mathrm{~mm}$ 증가한다. 또한 일반적으로 $100 \mathrm{~kg}$ 이상의 비육돈은 생체중이 증가할수록 사료섭취량은 증가하나 사료효율 은 감소하고 일당증체량은 감소 혹은 감소하 는 경향을 나타낸다(Latorre 등, 2004; Piao 등, 2004). 한편 비육돈의 생체중이 근육의 색깔, $\mathrm{pH}$ 및 보수력에 미치는 영향은 보고된 결과들 이 일치하지 않는다(김과 진, 2003; Kim 등, 2005).

비육돈의 출하체중은 품종과 사양 프로그램 등과 같은 내적인 요인과 소비자 집단의 문화, 전통 및 선호도 등과 같은 외적인 요인에 의해 결정된다(김, 2003; Kim 등, 2005). 현재 비육돈 은 국가 및 지역에 따라 대부분 90 130 kg 범 위에서 출하되나 세계적으로 비육돈의 출하체 중은 계속적으로 증가하는 추세에 있다. 실 예 로 지난 20년간 미국에서는 비육돈의 출하체중 이 꾸준히 약 $13 \mathrm{~kg}$ 증가하여 현재 평균 약 $124 \mathrm{~kg}$ 에 달하고 있다(NASS, 2006). 이렇게 최 근 세계적으로 출하체중이 증가한 원인은 일차 적으로 성장형질과 관련하여 정육 생산을 극대 화하는 방향으로 종돈이 육종되어 왔고, 경제 적으로 정육형 비육돈일수록 적정 출하체중이 높아지기 때문이다.
우리나라에서도 비육돈의 출하체중은 1990년 대에 약 $20 \mathrm{~kg}$ 증가하였으나 2003년 이후에는 $110 \mathrm{~kg}$ 수준에 정체되고 있어 현재 구미의 출 하체중에 비해서는 $5 \sim 20 \mathrm{~kg}$ 낮은 수치를 나타 내고 있다. 그러나 국내에서 사용되고 있는 대 부분의 종돈은 구미에서 유래된 정육형일 뿐만 아니라, 구미의 돈육 소비자와는 달리 국내 소 비자는 삼겹살과 같은 지방 비율이 높은 부위 를 선호하기 때문에 국내 비육돈의 출하체중은 적정 수준보다 낮을 가능성 매우 높다. 이러한 점을 간파하고 기 보고된 연구결과 등을 분석 하여 김(2003) 및 김과 진(2003)은 소비자의 기 호성은 물론 양돈의 생산성 측면에서도 국내 비육돈의 출하체중은 $110 \mathrm{~kg}$ 보다는 $130 \mathrm{~kg}$ 수 준이 적절할 것이라는 결론을 내린 바 있다. 이와는 다소 대조적으로 Piao 등(2004)은 생체 중 $27 \mathrm{~kg}$ 부터 암퇘지와 거세돼지를 육성 - 비육 하여 $100 \sim 130 \mathrm{~kg}$ 생체중시 매 $10 \mathrm{~kg}$ 간격으로 도축한 후 성장효율, 육질특성 및 경제성을 분 석한 결과 110 혹은 $120 \mathrm{~kg}$ 출하가 육질과 경 제성 면에서 가장 우수하였다고 보고하였다. 그러나 이 연구에서 출하체중간 가시적인 육질 특성상의 차이는 없었고, 출하 말기 즉 100 $130 \mathrm{~kg}$ 생체중 구간의 생산성 변화와 부분육 수율은 조사되지 않았다. 따라서 본 연구는 경 남 지역에서 가장 널리 사용되고 있는 계통의 비육돈을 $110 \mathrm{~kg}$ 대비 $130 \mathrm{~kg}$ 에 출하 - 도축하고 성장효율, 부분육 수율, 근육의 이화학적 특성 및 경제적 타당성을 분석하여 국내 비육돈 출 하체중의 상향 조정 가능성 여부를 확인하고자 착수되었다.

\section{ㅍ. 재료 및 방법}

\section{1. 공시돈}

경남 소재 “O” 농장에서 생체중 약 $90 \mathrm{~kg}$ 의 정육형 계통의 (Yorkshire $\times$ Landrace) $\times$ Duroc 3 원 교잡종 암퇘지와 거세돼지 각각 160 두씩 총 320 두를 선발하여 2(성; 암 vs. 거세) $\times 2$ (도살체 중; $110 \mathrm{~kg}$ vs. $130 \mathrm{~kg}$ ) 'factorial' 실험설계 하에 
돈방당 20두씩 16 돈방에 임의로 배치한 다음 사양시험에 착수하였다. 공시돈에게는 가소화 에너지와 조단백질 함량이 각각 $3,200 \mathrm{kcal} / \mathrm{kg}$ 와 15.5\%인 옥수수 - 대두박 위주의 실험사료(Table 1)를 무제한 급여하였다.

Table 1. Composition of the diet (as-fed basis)

\begin{tabular}{lc}
\hline Item & Content \\
\hline \hline Ingredients, \% & 60.69 \\
Corn & 14.20 \\
Wheat bran & 18.92 \\
Soybean meal (44\%) & 0.92 \\
Limestone & 0.35 \\
Dicalcium phosphate (18\%) & 0.25 \\
Salt & 0.27 \\
Vitamin premix & \\
Mineral premix & 0.25 \\
Liquid molasses & 4.00 \\
L- lysine & 0.14 \\
\hline
\end{tabular}

Calculated chemical composition

$\mathrm{DE}, \mathrm{Mcal} / \mathrm{kg}$

Crude protein, \%

Lysine, \%

0.90

Crude fat, \%

Crude fiber, \%

4.00

Crude ash, \%

Ca, \%

0.60

$\mathrm{P}, \%$

0.45

${ }^{a}$ Provided per kg of diet: 8,100 IU vitamin A, 1,200 IU vitamin $\mathrm{D}_{3}, 45 \mathrm{IU}$ vitamin $\mathrm{E}, 2.25 \mathrm{mg}$ vitamin $\mathrm{K}, 1.5$ $\mathrm{mg}$ thiamin, $0.6 \mathrm{mg}$ riboflavin, $2.55 \mathrm{mg}$ pyridoxine, $0.03 \mathrm{mg}$ vitamin $\mathrm{B}_{12}, 19.5 \mathrm{mg}$ pantothenic acid, $39 \mathrm{mg}$ niacin, $0.09 \mathrm{mg}$ biotin and $0.75 \mathrm{mg}$ folic acid.

${ }^{\mathrm{b}}$ Provided per kg of diet: $102.7 \mathrm{mg} \mathrm{FeSO}_{4}, 0.442 \mathrm{mg}$ $\mathrm{CoSO}_{4}, \quad 67 \mathrm{mg} \mathrm{CuSO}_{4}, \quad 54.18 \mathrm{mg} \mathrm{MnSO}_{4}, 69 \mathrm{mg}$ $\mathrm{ZnSO}_{4}, 0.546 \mathrm{mg} \mathrm{CaIO}_{3} \& 0.338 \mathrm{mg} \mathrm{Na} \mathrm{NeO}_{3}$.

\section{2. 도체 분석}

계획된 체중에 도달한 공시돈을 모두 1 주일 간격으로 부경양돈농협 축산물 공판장에 출하 - 도축하여 도체중, 등지방두께 등을 측정하고, 등지방두께 측정치는 예정된 도살체중(110 혹 은 $130 \mathrm{~kg}$ ) 기준으로 보정하였다(NSIF, 1997). 실험구당 20 두씩 총 80 두에 대해서는 부분육 무게를 측정하고 배최장근 시료를 채취하여 전 술(Lee 등, 2002)한 바와 같이 CIE(1978) 명도 $\left(\mathrm{L}^{*}\right)$, 적색도 $\left(\mathrm{a}^{*}\right)$ 및 황색도 $\left(\mathrm{b}^{*}\right)$ 와 $24-\mathrm{h} \mathrm{pH}$ 및 48-h 육즙삼출율을 측정하였다. 이들 80 두의 공 시돈은 3 일에 걸쳐 출하되었는데 이중 한 날짜

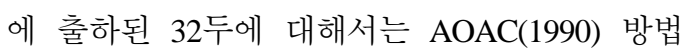
에 따라 배최장근의 수분, 조단백질 및 조지방 함량을 분석하였고, gas chromatography 방법 (Zanardi 등, 2000)으로 지방산 조성을 분석하였 다.

\section{3. 통계분석}

사료섭취량, 사료효율, 생체 및 도체 측정치 는 SAS(1996)의 General Linear Model Procedure 를 이용하여 분석하였다. 사료섭취량과 사료효 율 분석은 돈방을 실험단위로 하였고, 그 외 모든 변수에 대해서는 공시돈을 실험단위로 취 급하였으며, 분석 모델에는 성, 도살체중 및 성 $\times$ 도살체중 간의 상호작용을 고정오차로 삽입 하였다.

\section{4. 수익성 분석}

$110 \mathrm{~kg}$ 대비 $130 \mathrm{~kg}$ 출하의 수익성은 최종 20 $\mathrm{kg}$ 을 더 비육함으로써 발생하는 한계수익을 산 정함으로써 분석하였다. 즉 한계수익은 최종 $20 \mathrm{~kg}$ 을 더 비육함으로써 발생된 도체 판매 수 입에서 $20 \mathrm{~kg}$ 의 추가 비육에 소요된 사료비와 기타 생산비를 감하여 계산하였다.

\section{III. 결 과}

\section{1. 성장효율}


Table 2. Growth performance of finishing gilts and barrows slaughtered at $130-\mathrm{vs} .110-\mathrm{kg}$ live weight

\begin{tabular}{|c|c|c|c|c|c|c|}
\hline \multirow{2}{*}{ Item } & \multicolumn{2}{|c|}{ Gilts } & \multicolumn{2}{|c|}{ Barrows } & \multirow{2}{*}{ Pooled SE } & \multirow{2}{*}{ Significance } \\
\hline & $110 \mathrm{~kg}^{\mathrm{a}}$ & $130 \mathrm{~kg}^{\mathrm{a}}$ & $110 \mathrm{~kg}^{\mathrm{a}}$ & $130 \mathrm{~kg}^{\mathrm{a}}$ & & \\
\hline Initial wt, kg & 89.1 & 90.4 & 90.6 & 91.5 & 0.66 & Sex* \\
\hline Final wt, kg & 110.9 & 128.9 & 111.2 & 130.5 & 0.59 & Slaughter $\mathrm{wt}^{* *}$ \\
\hline $\mathrm{ADG}, \mathrm{kg}$ & 0.79 & 0.80 & 0.88 & 0.83 & 0.02 & Sex** \\
\hline $\mathrm{ADFI}^{\mathrm{b}}, \mathrm{kg}$ & 3.03 & 3.24 & 3.26 & 3.58 & 0.07 & Sex**, Slaughter $\mathrm{wt}^{* *}$ \\
\hline Gain:feed $^{\mathrm{b}}$ & 0.247 & 0.235 & 0.248 & 0.224 & 0.007 & Slaughter wt* \\
\hline Backfat $^{\mathrm{c}}, \mathrm{mm}$ & 17.6 & 21.6 & 20.8 & 25.1 & 0.45 & Sex**, Slaughter $\mathrm{wt}^{* *}$ \\
\hline
\end{tabular}

${ }^{\mathrm{a}}$ Data are means \pm SE of 80 animals in each sex $\times$ slaughter wt., unless indicated otherwise.

${ }^{\mathrm{b}}$ Pen was the experimental unit $(\mathrm{n}=4$ in each sex $\times$ slaughter $\mathrm{wt})$.

c Adjusted for 110- or 130-kg targeted slaughter wt.

$* \mathrm{P}<0.05 ; * * \mathrm{P}<0.01$.

Table 2에 보는 바와 같이 일당증체량은 거 세돼지가 암퇘지보다 높았으나(0.86 vs. $0.79 \mathrm{~kg}$; $\mathrm{P}<0.01), 110 \mathrm{~kg}$ 대비 $130 \mathrm{~kg}$ 도살체중 구 간에 는 차이가 없었다 $(0.83$ vs. $0.81 \mathrm{~kg})$. 일당사료섭 취량은 거세돼지 $(3.42 \mathrm{~kg} /$ 두 $)$ 가 암퇘지 $(3.13 \mathrm{~kg} /$ 두) 보다 높았고, $130 \mathrm{~kg}$ 에 출하된 실험구(3.41 $\mathrm{kg}$ )가 $110 \mathrm{~kg}$ 에 출하된 실험구(3.14 kg)보다 높 은 수치를 보임으로써 성에 관계없이 $110 \mathrm{~kg}$ 이상 '큰 돼지'는 $110 \mathrm{~kg}$ 이하의 비육돈보다 더 많은 사료를 섭취한다는 것을 보여주었다. 사 료효율은 두 성간에는 차이가 없었으나, $130 \mathrm{~kg}$ 도살체중 구(0.230)는 $110 \mathrm{~kg}$ 도살체중 구(0.248) 보다 낮았다.

등지방두께는 예상된대로 거세돼지 $(22.9 \mathrm{~mm})$ 가 암퇘지 $(19.6 \mathrm{~mm})$ 보다 높았고 $(\mathrm{P}<0.01), 130 \mathrm{~kg}$ 에 도살된 돼지 $(23.4 \mathrm{~mm})$ 가 $110 \mathrm{~kg}$ 에 도살된 돼 지(19.2 mm)보다 높았다. 그러나 암퇘지는 130 $\mathrm{kg}$ 에 도살되어도 등지방두께가 $22 \mathrm{~mm}$ 에도 미 치지 않았고, $130 \mathrm{~kg}$ 에 도살된 거세돼지의 등지 방두께도 $25 \mathrm{~mm}$ 정도에 머물렀다.

\section{2. 부분육 비율}

도체율은 두 성 간에 차이가 없었고, $130 \mathrm{~kg}$
도살체중 구(75.5\%)가 $110 \mathrm{~kg}$ 도살체중 구(74.4\%) 보다 높았다(Table 3). 부분육 정형 후 정육율은 암퇘지가 거세돼지보다 높았고(43.4 vs. 42.4\%), 도체율과는 다소 대조적으로 $130 \mathrm{~kg}$ 도살체중 구가 $110 \mathrm{~kg}$ 도살체중 구보다 다소 낮은 경향 $(\mathrm{P}=0.10)$ 을 보였으나 유의차는 없었다. 앞다리, 목살, 갈비 및 뒷다리 비율은 두 성 간 혹은 두 도살체중 간 차이가 없었다. 등심 비율은 암 퇘지가 거세돼지보다 높았고(13.3\% vs. 12.6\%) $110 \mathrm{~kg}$ 도살체중 구(13.2\%)는 $130 \mathrm{~kg}$ 도살체중 구(12.7\%)보다 높았다. 안심 비율 역시 암퇘지 가 거세돼지보다 높았고 $110 \mathrm{~kg}$ 도살체중 구가 $130 \mathrm{~kg}$ 도살체중 구보다 높았으나 본 부분육의 비율이 $2 \%$ 이하로 낮아 전체적인 정육 생산에 미치는 영향에는 큰 의미가 없었다. 삼겹살 비 율은 거세돼지가 암퇘지보다 높았고(21.2 vs. 20.5\%; $\mathrm{P}<0.01), 130 \mathrm{~kg}$ 도살체중 구(21.4\%)가 $110 \mathrm{~kg}$ 도살체중 구(20.2\%)보다 높아 실험구간 등지방두께의 상대적인 높낮이와 같은 양상을 나타내었다.

\section{3. 배최장근의 이화학적 특성}

배최장근의 명도( $\left.\mathrm{L}^{*}\right)$ 는 모든 실험구에서 50 
Table 3. Yields of primal cuts of finishing gilts and barrows slaughtered at $130-\mathrm{vs} .110-\mathrm{kg}$ live weight

\begin{tabular}{|c|c|c|c|c|c|c|}
\hline \multirow{2}{*}{ Item } & \multicolumn{2}{|c|}{ Gilts } & \multicolumn{2}{|c|}{ Barrows } & \multirow{2}{*}{ Pooled SE } & \multirow{2}{*}{ Significance } \\
\hline & $110 \mathrm{~kg}$ & $130 \mathrm{~kg}$ & $110 \mathrm{~kg}$ & $130 \mathrm{~kg}$ & & \\
\hline Carcass $\mathrm{wt}^{\mathrm{a}}, \mathrm{kg}$ & 82.6 & 97.1 & 82.6 & 98.7 & 0.5 & Slaughter $\mathrm{wt}^{* *}$ \\
\hline Dressing $^{\mathrm{a}}, \%$ & 74.5 & 75.3 & 74.3 & 75.6 & 0.2 & Slaughter $\mathrm{wt}^{* *}$ \\
\hline Total lean', kg & 48.9 & 55.8 & 46.4 & 54.8 & 0.6 & Sex**, Slaughter wt** \\
\hline Lean percentage ${ }^{b}$ & 44.0 & 42.8 & 42.6 & 42.3 & 0.4 & Sex* \\
\hline \multicolumn{7}{|c|}{ Percentage of primal cut ${ }^{b}$} \\
\hline Picnic & 17.4 & 17.0 & 17.5 & 17.3 & 0.17 & \\
\hline Shoulder & 8.6 & 8.7 & 8.7 & 8.5 & 0.13 & \\
\hline Loin & 13.7 & 12.9 & 12.8 & 12.5 & 0.19 & Sex**, Slaughter wt** \\
\hline Tenderloin & 2.0 & 1.8 & 1.8 & 1.7 & 0.04 & Sex**, Slaughter wt** \\
\hline Rib & 7.3 & 7.5 & 7.6 & 7.6 & 0.14 & \\
\hline Belly & 19.8 & 21.2 & 20.7 & 21.6 & 0.30 & Sex**, Slaughter wt** \\
\hline Ham & 31.2 & 30.9 & 30.8 & 30.8 & 0.29 & \\
\hline Total & 100.0 & 100.0 & 100.0 & 100.0 & - & \\
\hline
\end{tabular}

${ }^{a}$ Data are means of 80 animals in each sex $\times$ slaughter wt.

b Data are means of 20 animals in each sex $\times$ slaughter wt after trimming.

$* \mathrm{P}<0.05 ; * * \mathrm{P}<0.01$.

Table 4. Color, $\mathrm{pH}$ and drip loss of the longissimus muscle of finishing gilts and barrows slaughtered at $130-$ vs. $110-\mathrm{kg}$ live weight

\begin{tabular}{|c|c|c|c|c|c|c|}
\hline \multirow{2}{*}{ Item } & \multicolumn{2}{|c|}{ Gilts } & \multicolumn{2}{|c|}{ Barrows } & \multirow{2}{*}{ Pooled SE } & \multirow{2}{*}{$\begin{array}{l}\text { Signif- } \\
\text { icance }\end{array}$} \\
\hline & $110 \mathrm{~kg}$ & $130 \mathrm{~kg}$ & $110 \mathrm{~kg}$ & $130 \mathrm{~kg}$ & & \\
\hline \multicolumn{7}{|l|}{ Color $^{\mathrm{a}, \mathrm{b}}$} \\
\hline CIE L* & $53.6 \pm 1.12$ & $55.1 \pm 1.21$ & $55.7 \pm 1.27$ & $54.7 \pm 1.17$ & - & \\
\hline CIE a* & $7.65 \pm 0.54$ & $7.33 \pm 0.59$ & $7.56 \pm 0.61$ & $7.92 \pm 0.57$ & - & \\
\hline $\mathrm{pH}^{\mathrm{c}}$ & 5.56 & 5.54 & 5.56 & 5.59 & 0.02 & \\
\hline Drip loss ${ }^{c}, \%$ & 2.33 & 2.75 & 2.29 & 2.45 & 0.20 & \\
\hline \multicolumn{7}{|c|}{ Attached backfat color ${ }^{\mathrm{a}, \mathrm{b}}$} \\
\hline CIE L* & $78.3 \pm 0.43$ & $79.7 \pm 0.56$ & $78.8 \pm 0.54$ & $79.3 \pm 0.43$ & - & \\
\hline CIE b* & $5.28 \pm 0.26$ & $5.45 \pm 0.34$ & $5.08 \pm 0.33$ & $5.15 \pm 0.26$ & - & \\
\hline
\end{tabular}

${ }^{a}$ Data are LS means \pm SE of $17,10,11$ and 18 animals from the left to the right of each row.

${ }^{\mathrm{b}}$ Live wt was included in the model as a covariate.

${ }^{c}$ Data are means of 20 animals in each sex $\times$ slaughter wt. 
이상의 값을 보임으로써 $\operatorname{PSE}\left[\mathrm{pale}\left(\mathrm{L}^{*}>50\right)\right.$, soft and exudative] 돈육의 수치(Warner 등, 1997)를 나타냈으나, $\mathrm{pH}$ 와 육즙삼출율은 각각 $5.0 \sim 6.0$ 및 $5.0 \%$ 이하의 정상 수치를 나타냄으로써 (Table 4) 거의 모든 공시돈이 RFN(reddish-pink, firm and non-exudative) 범주의 정상도체를 산 출하였다. 배최장근의 명도, 적색도 $\left(\mathrm{a}^{*}\right), \mathrm{pH}$, 육 즙삼출율(drip loss) 및 배최장근과 인접한 등지 방의 황색도(b*)는 두 성 간 혹은 도살체중 간 차이가 없었다.

배최장근의 수분 함량은 다소 역설적으로 $130 \mathrm{~kg}$ 에 도축된 암퇘지가 $110 \mathrm{~kg}$ 에 도축된 암 퇘지보다 약간 높았으나 $(\mathrm{P}<0.05)$, 두 성 간 혹 은 두 도살체중 간에는 차이가 없었다(Table 5). 조단백질 및 조지방 함량에서는 성, 도살체중 및 이들 두 고정오차 간의 상호작용의 효과가 검출되지 않았다. 배최장근의 지방산 조성에 있어서는, $130 \mathrm{~kg}$ 에 도축된 돼지가 $110 \mathrm{~kg}$ 에 도 축된 돼지에 비해 myristic(14:0) \& stearic(18:0) acids 같은 포화지방산과 oleic(18:1) acid 같은 단가 불포화지방산(mono-unsaturated fatty acid) 의 함량이 낮은 반면 $\operatorname{linoleic(18:2)~acid~ㄱㅏㅌㅇㅡㄴ~}$ poly-unsaturated fatty acid의 함량이 높았던 것 이 주목할만 하였다.

\section{4. $130 \mathrm{~kg}$ 출하의 수익성}

현재 비육돈은 평균적으로 $110 \mathrm{~kg}$ 에 출하되 므로 $130 \mathrm{~kg}$ 고체중 비육돈 생산의 수익성은 최종 $20 \mathrm{~kg}$ 을 더 비육함으로써 발생한 한계수 익(한계수입 - 한계비용)을 계산함으로써 판정 하였다. “O” 농장의 경우 $20 \mathrm{~kg}$ 을 더 비육하기 위한 비용(한계생산비)은 두당 약 28,000 원이 소요되었다(Table 6). 그러나 현재 도체등급제 도는 등급별 도체중의 범위를 적용하기 때문에 대부분의 $130 \mathrm{~kg}$ 출하돈이 C \& D 등급을 받았 고, 두당 7,000 여 원의 과체중 벌칙금까지 받은 결과 한계수입은 두당 8,632원 밖에 되지 않았

Table 5. Chemical composition of the longissimus muscle of finishing gilts and barrows slaughtered at $130-$ vs. $110-\mathrm{kg}$ live weight

\begin{tabular}{lccccccc}
\hline & \multicolumn{3}{c}{ Gilts } & & \multicolumn{2}{c}{ Barrows } & \\
\cline { 2 - 3 } Item & $\begin{array}{c}110 \mathrm{Kg}^{\mathrm{a}} \\
(\mathrm{n}=5)\end{array}$ & $\begin{array}{c}130 \mathrm{Kg}^{\mathrm{a}} \\
(\mathrm{n}=10)\end{array}$ & & $\begin{array}{c}110 \mathrm{Kg}^{\mathrm{a}} \\
(\mathrm{n}=11)\end{array}$ & $\begin{array}{c}130 \mathrm{Kg}^{\mathrm{a}} \\
(\mathrm{n}=6)\end{array}$ & Significance \\
\hline \hline Moisture, \% & $72.6 \pm 0.5$ & $73.9 \pm 0.4$ & & $73.3 \pm 0.3$ & $72.7 \pm 0.5$ & Sex $\times$ Slaughter wt* \\
Crude protein, \% & $22.9 \pm 0.18$ & $22.6 \pm 0.13$ & & $22.6 \pm 0.12$ & $22.7 \pm 0.17$ & \\
Crude fat, \% & $2.85 \pm 0.13$ & $2.81 \pm 0.09$ & & $2.91 \pm 0.09$ & $3.10 \pm 0.12$ & \\
\hline
\end{tabular}

Fatty acid composition, \%

\begin{tabular}{rrrrrl}
$14: 0$ & $0.69 \pm 0.06$ & $0.58 \pm 0.04$ & $0.68 \pm 0.04$ & $0.56 \pm 0.05$ & Slaughter wt* \\
$16: 0$ & $20.2 \pm 0.60$ & $18.5 \pm 0.42$ & $18.7 \pm 0.40$ & $20.1 \pm 0.55$ & Sex $\times$ Slaughter wt** \\
$18: 0$ & $9.65 \pm 0.35$ & $8.79 \pm 0.25$ & $9.50 \pm 0.24$ & $8.79 \pm 0.32$ & Slaughter wt* \\
$16: 1$ & $2.59 \pm 0.22$ & $2.29 \pm 0.16$ & $2.65 \pm 0.15$ & $2.21 \pm 0.20$ & \\
$18: 1$ & $35.1 \pm 1.5$ & $31.6 \pm 1.1$ & $34.6 \pm 1.0$ & $32.4 \pm 1.4$ & Slaughter wt* \\
$18: 2$ & $22.9 \pm 1.2$ & $25.4 \pm 0.9$ & $22.6 \pm 0.8$ & $25.5 \pm 1.1$ & Slaughter wt* \\
$20: 4$ & $8.87 \pm 1.01$ & $12.81 \pm 0.71$ & $11.22 \pm 0.68$ & $10.49 \pm 0.92$ & Sex $\times$ Slaughter wt** \\
\hline
\end{tabular}

\footnotetext{
${ }^{\text {a }}$ Data are means $\pm \mathrm{SE}$.

$* \mathrm{P}<0.05$; ** $\mathrm{P}<0.01$.
} 
Table 6. Profitability of production of $130-\mathrm{kg}$ market pigs of the "O" swine farm

\begin{tabular}{|c|c|c|}
\hline Item & $\begin{array}{l}\text { Calculation } \\
\text { (amount/head) }\end{array}$ & $\begin{array}{l}\text { Amount } \\
\text { (won) }\end{array}$ \\
\hline \multicolumn{3}{|l|}{ Marginal production cost } \\
\hline - Feed cost & $20 \mathrm{~kg}$ gain $\div 0.239 \mathrm{~kg}$ gain $/ \mathrm{kg}$ feed $\times 275$ won $/ \mathrm{kg}$ feed & 23,012 \\
\hline - Other production costs & $20 \mathrm{~kg}$ gain $\div 0.824 \mathrm{~kg}$ gain $/ \mathrm{d} \times 200$ won $/ \mathrm{d}$ & 4,854 \\
\hline - Total & & 27,866 \\
\hline \multicolumn{3}{|c|}{ Marginal revenue and profit under the current carcass grading system (74.9\% dressing) } \\
\hline - Carcass revenue $\mathrm{a}^{\mathrm{a}, \mathrm{b}}$ & $130 \mathrm{~kg} \times 0.749 \times 3168.84 \mathrm{won} / \mathrm{kg}$ & 308,550 \\
\hline - Carcass revenue at $110 \mathrm{~kg}^{\mathrm{b}, \mathrm{c}}$ & $110 \mathrm{~kg} \times 0.749 \times 3550.92 \mathrm{won} / \mathrm{kg}$ & 292,560 \\
\hline - Over - weight penalty & 7,358 won & 7,358 \\
\hline - Marginal revenue & $308,550-292,560-7,358$ & 8,632 \\
\hline - Marginal profit & $8,632-27,866$ & $<-19,234>$ \\
\hline
\end{tabular}

Marginal revenue and profit after abolition of the current carcass grading system (74.9\% dressing)

- Marginal revenue ${ }^{\mathrm{b}, \mathrm{d}}$ $0.749 \times 20 \mathrm{~kg} \times 3,550.92 \mathrm{won} / \mathrm{kg}$

- Marginal profit $53,193-27,866$ [total marginal (production) cost]

a Ratios of A, B, C \& D grades (“O” Farm record): 5\%, 18\%, 40\% \& 37\%, respectively.

b Based on carcass price between December, 2005 and March of 2006.

c Ratios of A, B, C \& D grades: 57\%, 28\%, 10\% \& 5\%, respectively.

${ }^{\mathrm{d}}$ On the condition of the distribution of A, B, C \& D grades being identical to that at $110 \mathrm{~kg}$.

다. 이러한 결과 $130 \mathrm{~kg}$ 출하돈의 한계수익은 - 19,234원/두가 되어 상당한 손실이 발생하였 다.

그러나 만약 현행 도체등급별 도체중 범위가 철폐되고, $130 \mathrm{~kg}$ 출하돈의 $\mathrm{A}, \mathrm{B}, \mathrm{C} \& \mathrm{D}$ 등 급 분포가 $110 \mathrm{~kg}$ 에 출하했을 때와 같을 것이 라는 전제조건 하에서 손익을 계산하면 두당 약 25,000원의 한계수익이 발생한다. 본 계산에 는 $130 \mathrm{~kg}$ 에 출하함으로써 삼겹살(12,900원 $/ \mathrm{kg})$ 비율의 증가로 인한 평균 정육가 상승(약 88원 $/ \mathrm{kg}$ )으로 얻을 수 있는 두당 약 4,800원의 부가 가치는 포함되지 않은 반면, $130 \mathrm{~kg}$ 에 출하하였 을 때 $110 \mathrm{~kg}$ 에 출하할 때보다 $\mathrm{A}, \mathrm{B}$ 등급 출현 율이 다소 저하되어 발생할 수 있는 한계수익 감소가 서로 상쇄되었다.
IV. 고 찰

경남 지역에서 가장 널리 사용되고 있는 계 통의 암 \& 거세 비육돈을 $90 \mathrm{~kg}$ 부터 $110 \mathrm{~kg}$ 및 $130 \mathrm{~kg}$ 까지 사육하여 도축하고 성장효율과 도 체 특성을 조사한 결과 $130 \mathrm{~kg}$ 까지 사육하여도 $0.8 \mathrm{~kg}$ 이상의 높은 일당증체량이 유지되고 등 지방두께 또한 $130 \mathrm{~kg}$ 에 도축된 거세돼지 $(25$ $\mathrm{mm}$ )를 제외한 전 실험구에서 $22 \mathrm{~mm}$ 이하의 낮은 수치를 나타냄으로써 본 지역의 대표적인 비육돈이 전형적인 정육형 계통임을 시사하였 다. 본 연구에서 관찰된 암퇘지 대비 거세돼지 및 $110 \mathrm{~kg}$ 대비 $130 \mathrm{~kg}$ 도살체중 구간의 상대적 인 일당증체량, 사료섭취량, 사료효율 및 등지 방두께 등의 생산효율은 개괄적으로 Piao 등 (2004)의 결과와 일치하였고, 일당증체량을 제 
외하면 Latorre 등(2004)의 결과와도 일치하였 다. 후자의 연구에서는 생체중 $116 \sim 134 \mathrm{~kg}$ 기 간 동안의 일당증체량이 $75 \sim 116 \mathrm{~kg}$ 기간 동안 의 일당증체량보다 현저히 낮았다.

부분육의 비율에 있어서 암퇘지와 거세돼지 공히 $110 \mathrm{~kg}$ 에 도축했을 때에 비해 $130 \mathrm{~kg}$ 도축 시 국내 최고가의 부분육인 삼겹살의 비율이 증가되어 부분육 수율 상으로도 '큰돼지'가 유 리할 수 있음을 시사하였다. 또한 본 공시돈의 낮은 등지방두께에서 추측할 수 있듯이 암퇘지 는 $130 \mathrm{~kg}$ 에 도축해도 삼겹살의 지방층이 다소 얇아 보였다(그림 미제시). 이와는 다소 대조적 으로 거세돼지 삼겹살의 지방층 두께는 $110 \mathrm{~kg}$ 도축 시에는 얇았으나 $130 \mathrm{~kg}$ 도축 시에는 다 소 두꺼워 보였다. 즉 이러한 결과는 $110 \mathrm{~kg}$ 거 세돼지는 비육이 덜 된 반면 $130 \mathrm{~kg}$ 거세돼지 는 다소 과비육 되었고, 암퇘지는 $130 \mathrm{~kg}$ 까지 사육하여도 다소 비육이 덜 된다는 해석을 내 릴 수도 있을 것이다. 도살체중을 $110 \mathrm{~kg}$ 에서 $130 \mathrm{~kg}$ 으로 증가시킴으로써 삼겹살 비율이 증 가한 본 연구결과는 Martin 등(1980)이 보고한 결과와도 일치한다. 반면, 본 연구에서는 130 $\mathrm{kg}$ 도살체중 구가 $110 \mathrm{~kg}$ 구보다 등심의 비율 은 다소 낮고 뒷다리의 비율은 두 구간 차이가 없었으나 Martin 등(1980)의 연구에서는 100 $137 \mathrm{~kg}$ 크기의 비육돈 생체중이 증가할수록 등 심의 비율은 선형으로 증가(100 \& $137 \mathrm{~kg}$ 시 각 각 $22.52 \% \& 23.4 \%)$ 한 반면 뒷다리의 비율은 다소 감소하였다 $100 \& 137 \mathrm{~kg}$ 시 각각 $25.1 \%$ \& 24.4\%). 두 결과간 이와 같은 차이에 대한 이유는 명확치는 않으나 아마도 두 연구에서 적용한 부분육 자르는 기준의 차이가 큰 이유 이었을 것으로 추측된다.

비육돈의 도살체중을 $110 \mathrm{~kg}$ 으로부터 $130 \mathrm{~kg}$ 으로 증가시켜도 PSE(pale, soft and exudative)와 $\mathrm{DFD}$ (dark, firm and dry) 같은 이상육(Warner 등, 1997) 판정의 기준이 되는 배최장근의 육 색, $\mathrm{pH}$ 및 육즙삼출율은 물론 조단백질과 조지 방 함량과 같은 이화학적 특성이 변하지 않았 다. 반면 생체중이 $20 \mathrm{~kg}$ 증가함으로써 몇몇 포 화지방산과 mono-unsaturated fatty acid의 함량 이 줄어들고 linoleic acid 같은 poly-unsaturated fatty acid의 함량이 증가되었으나 본 지방산 분 석에 사용된 공시돈의 수가 상대적으로 작았기 때문에 도살체중의 증가가 근육의 지방산 조성 및 돈육의 풍미에 미치는 영향을 구명하기 위 해서는 추가의 연구가 요망된다.

$110 \mathrm{~kg}$ 대비 $130 \mathrm{~kg}$ 비육돈 생산의 수익성 분석에서 나타났듯이 현재의 도체등급제도 하 에서는 $130 \mathrm{~kg}$ 출하돈 생산은 두당 $110 \mathrm{~kg}$ 출 하돈 생산비의 약 $10 \%(20,000$ 원 $)$ 에 해당하는 손실이 발생하였다. 이와 같은 손실은 현행 도 체등급제도 하에서 $120 \mathrm{~kg}$ 이상의 비육돈 도체 는 대부분 $\mathrm{A}, \mathrm{B}$ 등급 도체중 상한선을 넘게 되어 C \& D 등급을 판정 받기 때문에 발생하 는 결과로서 110 혹은 $120 \mathrm{~kg}$ 출하돈이 $130 \mathrm{~kg}$ 출하돈보다 수익성이 높았다고 보고한 Piao 등(2004)의 보고와도 일치한다. 그러나 만일 현행의 등급별 도체중 범위가 철폐되기만 한 다면 $110 \mathrm{~kg}$ 대비 $130 \mathrm{~kg}$ 비육돈은 두당 20,000 원 이상의 한계수익이 발생할 수 있을 것으로 추정되었고, 이러한 고체중 비육돈의 수익성은 번식비용(자돈생산비)이 커질수록 더욱 커질 것이다.

이상의 결과를 종합하면, 현행 도체등급제도 를 무시한 순수한 생산성 측면에서 경남 지역 의 대표적인 계통의 $\mathrm{YLD}$ 교잡종 암퇘지와 거 세돼지의 적정 도살(출하)체중은 각각 $135 \mathrm{~kg}$ $\& 125 \mathrm{~kg}$ 수준으로 판단되고, 이때 등지방두 께는 각각 $22.5 \& 24.0 \mathrm{~mm}$ 내외가 될 것으로 예측된다. 또한 도축업자와 소비자가 부여하는 도체 가치와 현행 도체등급제도가 부여하는 도체 가치의 차이점을 고려해서 도체등급별 도체중 범위를 상향 조정하는 것이 바람직할 것이다.

\section{V. 요 약}

양돈에 있어서 도살체중은 가장 중요한 경제 요인 중의 하나이다. 본 연구는 성장효율과 도 체 품질에 크게 영향을 미치지 않고 비육돈의 도살체중을 $130 \mathrm{~kg}$ 으로 증가시킬 수 있을 지의 여부를 알아보기 위해 착수되었다. 경남 지역 에서 비육돈으로 가장 널리 사용되고있는 정육 
형 (Yorkshire $\times$ Landrace) $\times$ Duroc(YLD) 3원 교 잡종 암퇘지 160 두와 거세돼지 160 두를 생체중 $90 \mathrm{~kg}$ 에 선발하여 2(성) $\times 2$ (도살체중; $110 \mathrm{vs}$. $130 \mathrm{~kg}$ ) ‘factorial' 실험설계 하에 16 돈방에 배치 하였다. 공시돈에게는 $3,200 \mathrm{kcal} / \mathrm{kg}$ 의 가소화 에너지와 $15.5 \%$ 의 조단백질을 함유하는 공시사 료를 무제한 급여하였고, 계획된 체중에 도달 하였을 때 도축하여 부분육 수율과 배최장근의 이화학적 특성을 조사하였다. 일당증체량은 거 세돼지가 암퇘지보다 높았으나 $(0.86$ vs. $0.79 \mathrm{~kg}$; $\mathrm{P}<0.01) 110 \mathrm{~kg}$ 대비 $130 \mathrm{~kg}$ 도살체중 구 사이 에는 차이가 없었다 $(0.83$ vs. $0.81 \mathrm{~kg} ; \mathrm{P}>0.05)$. 등지방두께는 암퇘지와 거세돼지 공히 $130 \mathrm{~kg}$ 도살체중 구가 $110 \mathrm{~kg}$ 도살체중 구보다 높았다 (암: 17.6 vs. $21.6 \mathrm{~mm}$, 거세: 20.8 vs. $25.1 \mathrm{~mm}$ ). 정육중 삼겹살 비율은 거세돼지가 암퇘지보다 높았고(21.2 vs. 20.5\%) $130 \mathrm{~kg}$ 도살체중 구 (21.4\%)가 $110 \mathrm{~kg}$ 도살체중 구(20.2\%)보다 높았 다. 배최장근의 색깔, 48 -시간 육즙삼출율, 24 - 시간 $\mathrm{pH}$, 조단백질 및 조지방 함량 등의 이 화학적 특성은 두 성간 혹은 두 도살체중간 차 이를 나타내지 않았다. $110 \mathrm{~kg}$ 대비 $130 \mathrm{~kg}$ 출 하돈의 한계수익은 두당 약 $-20,000$ 원에 달하 였는데, 이 같은 손실은 거의 전적으로 $130 \mathrm{~kg}$ 출하돈의 도체가 너무 커 $\mathrm{A}, \mathrm{B}$ 도체 등급의 도 체중 상한선을 초과했기 때문이다. 그러나 만 일 도체중 상한선이 철폐된다는 조건으로 계산 하면 $130 \mathrm{~kg}$ 출하돈당 20,000원 이상의 한계수 익이 발생할 수 있을 것으로 추정되었다. 이상 의 결과는 정육형 비육돈에서는 성장효율이나 육질에 크게 영향을 미치지 않고 도살체중을 $130 \mathrm{~kg}$ 까지 증가시킬 수 있고, 따라서 체중이 큰 출하돈을 수용하기 위해서는 ‘좋은 등급'의 도체중 상한선을 증가시킬 필요가 있음을 시사 한다.

$$
\text { VI. 사 사 }
$$

본 연구는 산업자원부와 한국산업기술평가원 이 지정한 진주산업대학교 동물생명산업 지역 협력연구센터의 연구비 지원으로 수행되었습니 다.

\section{VII. 인 용 문 헌}

1. AOAC. 1990. Official Methods of Analysis. $15^{\text {th }}$ ed. Association of Official Analytical Chemists. Arlington, VA, USA.

2. CIE. 1978. Recommendations on uniform color spaces-color difference equations, psychometric color terms. Supplements no. 2 to CIE Publication No. 15 (E-1.3.1) 1971/(TC-1-3). Commission Internationale de l'Eclairage, Paris.

3. Kim, Y. S., Kim, S. W., Weaver, M. A. and Lee, C. Y. 2005. Increasing the pig market weight: world trends, expected consequences and practical considerations. Asian-Aust. J. Anim. Sci. 18:590600.

4. Latorre, M. A., Lazaro, R., Valencia, D. G., Medel, P. and Mateos, G. G. 2004. The effects of gender and slaughter weight on the growth performance, carcass traits and meat quality characteristics of heavy pigs. J. Anim. Sci. 82: 526-533.

5. Lee, C. Y., Lee, H. P., Jeong, J. H., Baik, K. H., Jin, S. K., Lee, J. H. and Sohn, S. H. 2002. Effects of restricted feeding, low-energy diet, and implantation of trenbolone acetate plus estradiol on growth, carcass traits, and circulating concentrations of insulin-like growth factor (IGF)-I and IGFbinding protein-3 in finishing barrows. J. Anim. Sci. 80:84-93.

6. Martin, A. H., Sather, A. P., Fredeen, H. T. and Jolly, R. W. 1980. Alternative market weights for swine. II. Carcass composition and meat quality. J. Anim. Sci 50:699-705.

7. NASS. 2006. Agricultural Statistics. USDA. National Agricultural Statistics Service. US Government Printing Office, Washington, D.C.

8. NSIF. 1997. Guidance for Uniform Swine Improvement Programs. On-farm Programs. National Swine Improvement Federation, Raleigh, NC, USA.

9. Piao, J. R., Tian, J. Z., Kim, B. G., Choi, Y. I., Kim, Y. Y. and Han, I. K. 2004. Effects of sex 
and market weight on performance, carcass characteristics and pork quality of market hogs. Asian-Aust. J. Anim. Sci. 17:1452-1458.

10. Quijandria, B., Jr. and Robinson, O. W. 1971. Body weight and backfat deposition in swine: curves and correction factors. J. Anim. Sci. 33:911-918.

11. SAS. 1996. SAS User's Guide: Statistics, SAS Inst., Inc., Cary, NC, USA.

12. Warner, R. D., Kauffman, R. G. and Greaser, M. L. 1997. Muscle protein changes post mortem in relation to pork quality traits. Meat Sci. 45:339352.

13. Zanardi, E. E., Novelli, E., Ghiretti, G. P. and Chizzolini, R. 2000. Oxidative stability of lipids and cholesterol in salame Milano, coppa and Parma ham: dietary supplementation with vitamin E and oleic acid. Meat Sci. 55:169-175.
14. 김성우. 2003. 한국 양돈의 현실에 따른 출하체중 의 변화: 양돈업의 소득 향상과 소비자 인식 변화 에 대한 대처. “130 kg 출하돈은 어떻습니까?” 심 포지움, 2003년 11월 4일, 진주산업대학교 동물생 명산업 지역협력연구센터 주최, Proceedings pp. 51-71. Available:http://www.jinjuric.com/bbs/zboard. php?id=data.

15. 김용수, 진형주. 2003. $130-140 \mathrm{~kg}$ 으로 돼지 출하 체중 상향조정: 성장촉진제의 역할과 육질에 미 치는 영향. “ $130 \mathrm{~kg}$ 출하돈은 어떻습니까?” 심포 지움, 2003년 11월 4일, 진주산업대학교 동물생 명산업 지역협력연구센터 주최, Proceedings pp. 5-26. Available: http://www.jinjuric.com/bbs/zboard. php?id=data.

(접수일자 : 2006. 6. 15. / 채택일자 : 2006. 8. 18.) 